\title{
Investigating the Association between Sport Motivation with General Health in Faculty Members of Fars University of Medical Sciences (A Cross Sectional-Analytical Study in 2018)
}

\author{
Saeed Sobhanian' \\ Ebrahim Khoshnam" \\ Masoud Naderian"I \\ Hosein Dast Barhagh ${ }^{\text {IV }}$
}

\begin{abstract}
Motivation is one of the main indices in many theories of learning and psychology. Sports psychologists consider a variety of motivations, including the motivation for progress and achievement, the motivation for competition, the motivation for participation, etc. with specific concepts. Therefore, this study aimed to examine the association between sport motivations with general health in Fars University of medical sciences. This study was a cross sectional-analytical research. The research population consisted of faculty members of Fars University of medical sciences. Sampling was done randomly with a sample size of 244 people. Data were collected using demographic information, sport motivation questionnaire, and general health questionnaire. Descriptive statistics and analytical statistics were used to analyze the data using SPSS-16 software. The results of Pearson correlation test showed that there was a significant correlation between general health and sport motivation ( $P=0.001, r=-0.252$ ); among the components of sport motivation, only physical recovery dimensions, competition, weight control, and health do not have a significant correlation with the general health. The results of this study indicated an association between general health and sport motivation and some of its components in the study population. Therefore, the applying methods for increasing the athletic motivation to achieve the desired levels of general health and its components by modeling the results can be useful for planners and managers of human resources in universities.
\end{abstract}

Keywords: General health; Sport motivation; Exercise and physical activity; Health promotion; Faculty members

IPh.D Student in Physical Education, Jahrom Branch, Islamic Azad University, Jahrom, Iran Sobhanian@Aftermail.Ir

"Department of Physical Education, Jahrom Branch, Islamic Azad University, Jahrom, Iran Khoshnam@Aftermail.Ir

I'Department of Physical Education, Isfahan University, Isfahan, Iran - Naderian@Aftermail.Ir

IV Department of Physical Education, Jahrom Branch, Islamic Azad University, Jahrom, Iran -

barhagh@aftermail.ir 


\section{Introduction}

Health is one of the basic human needs (Chhea et al., 2010), which plays a vital role in the sustainable development of societies (Safair and Fattahzadeh, 2003). According to the World Health Organization, being healthy does not mean the absence of disease and injury, but it includes physical, mental and social health (Larson, 1996; Ekrami and Mirhaj, 2015). Today, according to WHO estimation, the level of mental and behavioral problems in developing countries is increasing, and this is greatly related to population growth and rapid social change, such as urbanization, family breakdown, lifestyle changes, and economic problems (Yagubi, 1995). Therefore, the industrialization of societies and, consequently, the reduction of mobility and physical activity in individuals have attracted widespread attention to exercise, especially in the psychological field of sport (Cox, 2011). According to Coakley, sport is an official competition with intense physical effort, using complex physical skills in individuals who exercise with motivation and the combination of internal and external motivating elements (Coakley, 2014).

According to this definition, sport motivation is needed to induce exercise behavior. The desire to do work or motivation is a key factor in individual mobility and activities. Therefore, motivation is one of the important instruments in inducing individuals to create effective results and create a positive activity environment and successfully implements predicted programs (Bessell et al., 2012). The total psychologists of sports believe that only one factor or motive does not cause behavior. For example, in sport participation, various motivations such as social interaction, pleasure and vitality, prevention and treatment, reduction of psychological stress, weight control, life, and occupational relationships, health and fitness, etc. cause someone tends to exercises (Ramezani Khalil Abadi, 1996). In this field, Frederic Ryan's research in 1993 showed that the motivation of people participating in sports competitions is different from the motivation of participants in sports and recreational activities (Frederick and Ryan, 1993). In competitive sports, individuals focus on external motivating resources, while in recreational activities, people are more likely to be motivated by internal motivation such as maintaining health, increasing physical fitness, enjoying and 
being together with friends, improving the mental and psychological status, and stress reduction in sports activities (Teixeira et al. , 2012; Gill et al., 2017). Other researches' findings also show that the incentive to exercise and physical activities, especially in leisure time, depends on factors such as gender, age, and culture of the community (lannotti et al., 2012), and the main motivation for people is to maintain health and fitness (Jafari Siavashani et al., 2010); because inadequate activities and stationery is responsible for $20 \%$ of deaths caused by cardiovascular disease, cancer and diabetes, and changes in lifestyle, such as physical activity and exercise is an important factor in reducing mortality and increasing longevity (Brill, 2004; Sharifirad et al., 2007).

However, today most people do not have the motivation and interest to do physical activity and prefer to spend time with friends and relatives or continuing their education and work (Teixeira et al., 2012). Therefore, activity poverty has caused some inadequacies in the physical, psychological and intellectual dimensions of the various classes of the society. One of these population groups is university professors. They are responsible for education in universities as important professionals in the community, so their physical, mental and psychological health is very important (Thorp et al., 2012).

In this regard, attention to physical activity and sport of this group of society requires the recognition of sport motivational dimensions and the restoration of these motivations in them and what comes out of the definition of exercise, as well as the physiological conditions of the body, clearly refers to providing health through exercise.

According to the definition of health from the perspective of the World Health Organization, it is clear that attention to its dimensions is important for measuring health. In this definition, three dimensions of physical, mental and social health are considered (Larson, 1996; Yazdi Feyzabadi et al., 2018), which are used in measuring general health. This can be achieved through the Goldberg questionnaire. Therefore, the purpose of this study was to investigate the association between sport motivation and general health in faculty members of Fars University of Medical Sciences in 2018. 


\section{Materials and Methods}

This is cross-sectional descriptive research. The study population consists of faculty members of Fars University of medical sciences. This study was done after approving the ethics code in Jahrom University of Medical Sciences (IR.JUMS.REC.1396.149) and obtaining permission for a random sampling study with a sample size of 244 people.

The data collection instrument consists of three sections: The first part consists of 3 questions about the individual characteristics of the research units including age, gender, and household income. The second section consists of a questionnaire of sport motivation; this questionnaire has 51 items and consists of 14 subscales: stress management, weight management, recreation, social approval, enjoyment, challenge, appearance, personal growth, affiliation, disease prevention, competition, strength and agility, physical ability and medical compulsion.

In a study done by Markland and Ingledew on the psychometric properties of this questionnaire, Cronbach's alpha coefficient for the subscales of the questionnaire was as follows: stress management 0.91 , physical recovery 0.832 , enjoyment 0.89 , challenge 0.85 , social approval 0.87, affiliation 0.91, competition 0.95, medical compulsion 0.68 disease prevention 0.90 , health 0.87 , weight management 0.91 , appearance 0.85 , strength 0.86 , and agility 0.89 (Markland and Ingledew, 1997).

In the study done by Erfani, the formal validity of the questionnaire was confirmed by the professors of psychology and physical education. The reliability of this questionnaire was also calculated in the internal consistency method using Cronbach's alpha (Erfani, 2013). The Cronbach's alpha coefficient for the subscales of this questionnaire was 0.70 to 0.90 . Scoring the items of this questionnaire was based on a six-score scale from zero to five: (totally opposite: 0 , opposite: 1 , slightly opposite: 2 , slightly agree: 3, agree: 4, totally agree: 5 ). Questions related to each dimension include stress management $(46,34,20,6)$, physical recovery $(31,17,3)$, enjoyment $(4,37,23,9)$, challenge $(51,42,28,14)$, social approval $(45$, $33,19,5)$, affiliation $(49,38,24,10)$, competition $(50,40,26,12)$, medical compulsion $(39,25$, $11)$, disease prevention $(30,16,2)$, health $(35,21,7)$, weight management $(43,29,15,1)$, 
appearance $(44,32,18,4)$, strength $(47,36,22,8)$, and agility $(41,27,13)$. In this questionnaire, the scores of each scale were calculated in terms of its questions, and then the total score of the subscale is divided by the numbers of its questions; the highest score of the questionnaire was"225" and the lowest was"0". The closer the person's score to 255 , he is more motivated to exercise.

The third section also included the General Health Questionnaire (GHQ). The 28general health question questionnaire was presented by Goldberg and Hiller in 1979, which had 4 sub-scales and each sub-scale had 7 questions. These scales included: 1 . physical symptoms scale 2. scale of anxiety symptoms and sleep disorders 3. social function scale 4 . depression symptoms scale.

Goldberg and Williams in 1988 reported reliability 0.95 for the questionnaire, completed by 835 ones (Goldberg and Williams, 1988).

In the study done by Taghavi, the reliability coefficient of this instrument was obtained 0.93, 0.70 and 0.90 respectively, with three retests (Taghavi, 2001).

Also, in this study, for evaluating the validity of the general health questionnaire, simultaneous validity and factor analysis methods have been used. Validity of the general health questionnaire was reported 0.55 through simultaneous implementation with the Middlesex Hospital Questionnaire (MHQ). Finally, data collected were analyzed after entering and processing by SPSS-16 software. The descriptive statistics including mean, standard deviation and frequency distribution were used to analyze the data. Pearson correlation coefficient was used to assess the association of sport motivation and its subscales with general health components and general health score.

\section{Results}

After collecting data and entering it into SPSS-16 software and data processing, it was determined that among 244 individuals sampled in the study, 133 ones were male and 111 ones were female. The mean and standard deviation of age was $39.84 \pm 6.58$, and the mean and the standard deviation of their income was $6270000 \pm 2870000$ Toman per month. The 
mean and standard deviations of the main variables of the research are presented in table 1.

Table 1 - Central indices and distribution of main variables

\begin{tabular}{|c|c|c|c|c|}
\hline Standard deviation & Mean & Maximum & Vinimum & Variables \\
\hline Total Score of General Health & 4.942 & 16.901 & 39 & 7 \\
\hline Physical symptoms & 3.186 & 5.110 & 21 & 0.00 \\
\hline $\begin{array}{l}\text { Psychiatric symptoms } \\
\text { (anxiety and sleep disorder) }\end{array}$ & 2.234 & 3.479 & 12 & 0.00 \\
\hline Symptoms of social function & 2.477 & 5.176 & 18 & 2 \\
\hline Symptoms of depression & 1.316 & 3.176 & 10 & 0.00 \\
\hline Stress management & 0.784 & 3.479 & 5 & 1.25 \\
\hline Physical recovery & 0.678 & 3.967 & 5 & 2.33 \\
\hline Enjoyment & 0.723 & 3.547 & 5 & 0.75 \\
\hline Challenge & 0.775 & 3.032 & 5 & 0.75 \\
\hline Social approval & 0.882 & 2.888 & 4.50 & 0.25 \\
\hline Affiliation & 0.824 & 3.147 & 5 & 0.25 \\
\hline Competition & 1.00092 & 2.728 & 5 & 0.25 \\
\hline Medical compulsion & 0.907 & 2.624 & 5 & 0.00 \\
\hline Disease prevention & 0.676 & 4.056 & 5 & 2.33 \\
\hline Health & 0.678 & 4.132 & 5 & 1.33 \\
\hline Weight management & 1.063 & 3.757 & 10.75 & 0.75 \\
\hline Appearance & 0.707 & 0.687 & 5 & 1.75 \\
\hline Strength & 0.894 & 3.792 & 10.50 & 1.50 \\
\hline Agility & 0.717 & 3.482 & 5 & 1.33 \\
\hline $\begin{array}{l}\text { Total score of sport } \\
\text { motivation }\end{array}$ & 7.555 & 48.322 & 66.17 & 26.17 \\
\hline
\end{tabular}

There was no significant correlation between gender with the general health and its components except for physical symptoms with gender. Below is a chart for the frequency 
of gender in terms of the components of physical symptoms (Figure 1). Chi-square test was used to examine this correlation (chi-square: 8.34 , df: 1 , p-value: 0.003 ).

Chart 1 - Frequency of gender in terms of component of physical symptoms

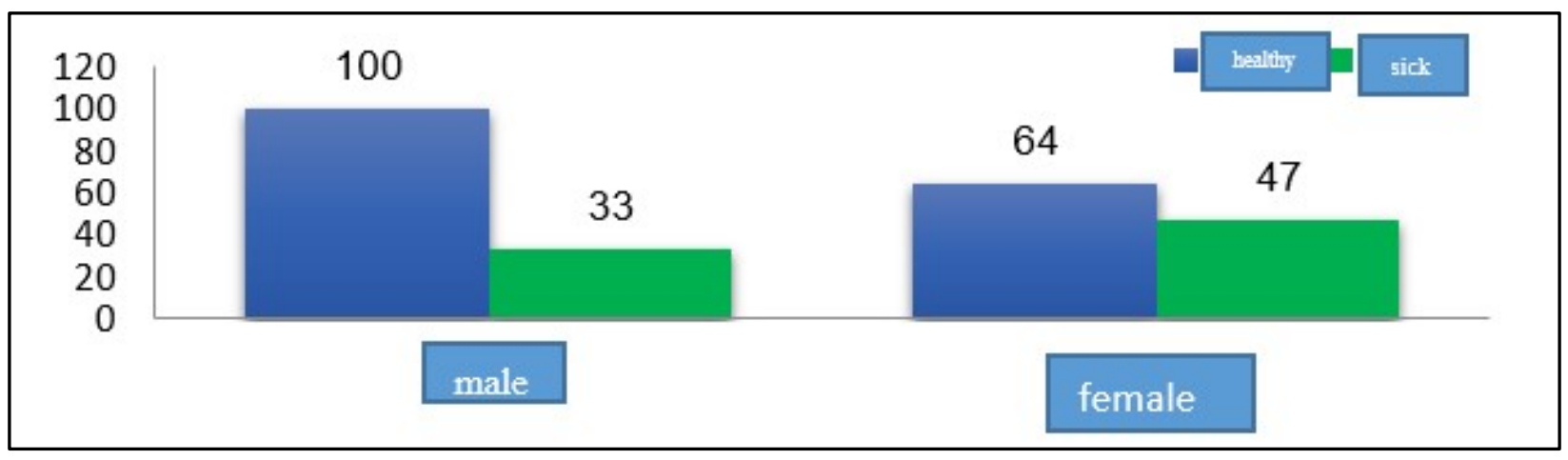

In the study of the correlation between the places of service of faculty members in medical science universities with the general health except the social function component, no significant correlation was found in any of the components, as well as the general health. To examine the correlation of Chi-square, the frequency of the city in terms of the social function of general health was reported in the table below (table 2).

Table 2 - City frequency in terms of the component of social function symptoms for general health

\begin{tabular}{|c|c|c|c|c|c|c|}
\hline \multirow{2}{*}{ City } & \multicolumn{2}{|c|}{ Social health } & \multirow{2}{*}{$\begin{array}{r}\text { Total } \\
\text { number } \\
\text { per city }\end{array}$} & \multirow{2}{*}{$\begin{array}{l}\text { Chi } \\
\text { value }\end{array}$} & \multirow{2}{*}{$\begin{array}{l}\text { Freedom } \\
\text { degree }\end{array}$} & \multirow{2}{*}{$\begin{array}{l}\text { Statistics } \\
\text { value }\end{array}$} \\
\hline & Healthy & Patient & & & & \\
\hline Shiraz & $95(94.1 \%)$ & $6(5.9 \%)$ & 101 & & & \\
\hline Jahrom & $52(62.7 \%)$ & $31(37.3 \%)$ & 83 & & & \\
\hline Fasa & $19(61.3 \%)$ & $12(38.7 \%)$ & 31 & 41.995 & 3 & 000.0 \\
\hline $\begin{array}{c}\text { Lar } \\
\text { \&Gerash }\end{array}$ & $29(100 \%)$ & $0(0 \%)$ & 29 & & & \\
\hline
\end{tabular}

Pearson correlation test was used to assess the association of sport motivation and its subscales with general health components (Table 3). 
Table 3 - Relationship between sport motivation and its components with general health and its components in the faculty members

\begin{tabular}{|c|c|c|c|c|c|c|c|}
\hline $\begin{array}{l}\text { General health } \\
\text { components }\end{array}$ & $\begin{array}{c}\text { Sport } \\
\text { motivation } \\
\text { components }\end{array}$ & $\begin{array}{l}\text { Statistical } \\
\text { index }\end{array}$ & $\begin{array}{l}\text { Physical } \\
\text { Symptoms } \\
\text { Scale }\end{array}$ & $\begin{array}{l}\text { Scale of } \\
\text { Anxiety } \\
\text { Symptoms } \\
\text { and Sleep } \\
\text { Disorders } \\
\end{array}$ & $\begin{array}{c}\text { Soci } \\
\text { al } \\
\text { Functio } \\
\text { n Scale }\end{array}$ & $\begin{array}{c}\text { Depression } \\
\text { Symptoms Scale }\end{array}$ & $\begin{array}{r}\text { Total } \\
\text { general } \\
\text { health }\end{array}$ \\
\hline \multirow{2}{*}{ Stress management } & & $\mathrm{R}$ & -0.31 & $-0.126^{*}$ & $\begin{array}{l}0.09 \\
4\end{array}$ & $-0.391^{\star *}$ & $\begin{array}{r}- \\
0.137^{*}\end{array}$ \\
\hline & & $\mathrm{P}$ & 0.628 & 0.049 & $\begin{array}{l}0.14 \\
3\end{array}$ & 0.000 & 0.033 \\
\hline \multirow{2}{*}{ Physical recovery } & & $\mathrm{R}$ & -0.113 & $0.156^{*}$ & $\begin{array}{l}0.06 \\
0\end{array}$ & $-0.199^{* *}$ & -0.032 \\
\hline & & $P$ & 0.079 & 0.015 & $\begin{array}{l}0.35 \\
2\end{array}$ & 0.002 & 0.614 \\
\hline \multirow{2}{*}{ Enjoyment } & & $\mathrm{R}$ & 0.056 & -0.106 & $\begin{array}{l}0.08 \\
6\end{array}$ & $-0.324^{\star *}$ & $\begin{array}{r}- \\
0.152^{*}\end{array}$ \\
\hline & & $P$ & 0.386 & 0.097 & $\begin{array}{l}0.18 \\
3\end{array}$ & 0.000 & 0.017 \\
\hline \multirow{2}{*}{ Challenge } & & $\mathrm{R}$ & -0.006 & $-0.154^{\star}$ & $\begin{array}{r}- \\
0.113\end{array}$ & $-0.369^{* *}$ & -0.238 \\
\hline & & $P$ & 0.920 & 0.016 & $\begin{array}{l}0.07 \\
7\end{array}$ & 0.000 & 0.000 \\
\hline \multirow{2}{*}{ Social approval } & & $\mathrm{R}$ & -0.071 & -0.116 & $0.188^{\star \star}$ & -0.274 & -0.272 \\
\hline & & $P$ & 0.270 & 0.071 & $\begin{array}{l}0.00 \\
3\end{array}$ & 0.000 & 0.000 \\
\hline \multirow{2}{*}{ Affiliation } & & $\mathrm{R}$ & -0.029 & $-0.183^{* \star}$ & $\begin{array}{r}- \\
0.007\end{array}$ & $-0.332^{\star *}$ & $\begin{array}{c}- \\
0.201^{\star *}\end{array}$ \\
\hline & & $P$ & 0.648 & 0.04 & $\begin{array}{l}0.91 \\
0\end{array}$ & 0.000 & 0.002 \\
\hline \multirow{2}{*}{ Competition } & & $\mathrm{R}$ & 0.112 & $-0.180^{* *}$ & $\begin{array}{r}- \\
0.058\end{array}$ & $-0.286^{* \star}$ & -0.121 \\
\hline & & $P$ & 0.080 & 0.005 & $\begin{array}{l}0.36 \\
9\end{array}$ & 0.000 & 0.059 \\
\hline Medical compulsion & & $\mathrm{R}$ & -0.029 & $-0.268^{* *}$ & $0.218^{\star *}$ & $-0.276^{\star \star}$ & $\begin{array}{c}- \\
0.324^{* *}\end{array}$ \\
\hline
\end{tabular}




\begin{tabular}{|c|c|c|c|c|c|c|}
\hline & $P$ & 0.650 & 0.000 & $\begin{array}{l}0.00 \\
1\end{array}$ & 0.000 & 0.000 \\
\hline \multirow[b]{2}{*}{ Disease prevention } & $\mathrm{R}$ & $-0.164^{*}$ & 0.046 & $\begin{array}{l}0.10 \\
7\end{array}$ & -0.107 & -0.062 \\
\hline & $P$ & 0.010 & 0.487 & $\begin{array}{l}0.09 \\
5\end{array}$ & 0.097 & 0.336 \\
\hline \multirow{2}{*}{ Health } & $\mathrm{R}$ & $-0.23^{* *}$ & $-0.126^{*}$ & $\begin{array}{l}0.08 \\
3\end{array}$ & $-0.163^{*}$ & -0.104 \\
\hline & $P$ & 0.001 & 0.049 & $\begin{array}{l}0.19 \\
5\end{array}$ & 0.011 & 0.106 \\
\hline \multirow{2}{*}{ Weight management } & $\mathrm{R}$ & $-0.126^{\star}$ & $0.156^{*}$ & $\begin{array}{l}0.13 \\
9^{*}\end{array}$ & $-0.229 * *$ & -0.116 \\
\hline & $P$ & 0.050 & 0.015 & $\begin{array}{l}0.03 \\
0\end{array}$ & 0.000 & 0.003 \\
\hline \multirow{2}{*}{ Appearance } & $\mathrm{R}$ & $-0.153^{*}$ & -0.106 & $\begin{array}{l}0.05 \\
0\end{array}$ & $-0.271^{* *}$ & $\begin{array}{c}- \\
0.186^{* *}\end{array}$ \\
\hline & $P$ & 0.017 & 0.097 & $\begin{array}{l}0.43 \\
9\end{array}$ & 0.000 & 0.003 \\
\hline \multirow{2}{*}{ Strength } & $\mathrm{R}$ & -0.076 & -0.154 & $\begin{array}{r}- \\
0.27\end{array}$ & $-0.323^{* *}$ & $\begin{array}{c}- \\
0.180^{* *}\end{array}$ \\
\hline & $P$ & 0.237 & 0.016 & $\begin{array}{l}0.66 \\
9\end{array}$ & 0.000 & 0.005 \\
\hline \multirow{2}{*}{ Agility } & $\mathrm{R}$ & -0.098 & -0.116 & $\begin{array}{r}- \\
0.006\end{array}$ & $-0.256^{* *}$ & $\begin{array}{c}- \\
0.180^{* *}\end{array}$ \\
\hline & $P$ & 0.125 & 0.071 & $\begin{array}{l}0.93 \\
1\end{array}$ & 0.000 & 0.005 \\
\hline \multirow{2}{*}{ Total score of sport motivation } & $\mathrm{R}$ & -0.092 & $-0.183^{\star \star}$ & $\begin{array}{r}- \\
0.024\end{array}$ & $-0.411^{\star *}$ & $\begin{array}{c}- \\
0.252^{* *}\end{array}$ \\
\hline & $P$ & 0.152 & 0.004 & $\begin{array}{l}0.71 \\
1\end{array}$ & 0.000 & 0.000 \\
\hline
\end{tabular}

The results of table 3 showed a significant relationship between general health and sport motivation $(P=0.001)$. Among the components of sport motivation, only the components of physical recovery, competition, weight management, and health had no significant relationship with the general health. 


\section{Discussion}

Motivation is in all human activities, but the amount and type vary depending on the circumstances. Motivation is one of the most important issues in the field of sport psychology (Deci and Ryan, 2013). According to the findings of this study, the average score of the general health of faculty members in the present study was $16.90 \pm 4.94$ which indicates their placement in the desired level of general health. In addition, the findings of this study suggest that there is not a significant correlation between gender with the general health and its components, except of physical health component, while the frequency of physical health in men is higher than that in women; this can be attributed to the individual characteristics of women, because the work environment has a greater impact on women's physical health than men. Brojerdi in his study reported that the general health of faculty members of physical education in universities is lower than average and also the general health of women is lower than that in men, which is consistent with the results of the research (Brojerdi et al., 2005). The other researches' results also suggest that the incentive to exercise and physical activities, especially in leisure time, is dependent on factors such as gender, age, and culture of the community (lannotti et al., 2012); it seems that the higher motivation in men, is also another reason for high level of public health. In studying the correlation between the cities of faculty members in medical universities with general health except for the component of social function symptoms, there was no significant correlation between the general subscales of general health with the general health. In this regard, the frequency of health in the component of social function symptoms in Shiraz City was reported more than Jahrom, Fasa, and Lar; one of the reasons for which could be the access and awareness of most residents of major cities to social and public health. The results of this study showed a significant correlation between general health and sport motivation ( $P=0.001)$, which is consistent with the results of the research done by Golmohammadi et al. (Golmohammadi et al., 2017). Among the components of sport motivation, only components of physical recovery, competition, weight management, and health did not have a significant correlation with the general health; it is important to note that in the correlation found, the remaining 
components are inverse with the general health and its components, and suggests that the symptoms of the disease are reduced with increasing the motivation. In studying on faculty members at state universities, Eshraghi et al. concluded that there was no significant correlation between general health and motor activity, but the general health of active people was better than those inactive (Eshraghi et al., 2012). Foster et al. did not report a significant correlation between general health and motor activity in their study (Foster, 1997), which is contrary to the results of this study. Pendo et al., in their study, reported that sports activities were effective in improving general health (Penedo and Dahn, 2005), which is consistent with the results of this study, given that the activity is caused by motivation. Exercise, in addition, to be a valuable instrument for maintaining the physical health of individuals, also establishes a close relationship with the mental health of individuals. Paluska and Schwenk conducted a study entitled "Concepts of physical activity and health" and reported that physical activity plays an important role in controlling and reducing mental illnesses, especially depression and anxiety (Paluska and Schwenk, 2000). The results of the research done by Ghodratnama and Heidarinejad also show that there was a significant positive correlation between social interaction and stress reduction and aggression with the amount of physical activity in the workplace (Ghodratnama and Heidarinejad, 2014). In the present study, there was a significant correlation between stress management caused by sport motivation and the general health of individuals.

\section{Conclusion}

The results of this study revealed that sport motivation and general health are associated. Therefore, based on the results of this study, it was suggested to the human resources managers of universities that pay special attention to sports motivators to maintain and improve the health of faculty members and professors of universities. In general, provision of sport facilities, extensive education in community and the necessary measures to encourage people to exercise, to consider programs for regular physical activity in groups on holidays and other suitable times and making-culture in order to promote the 
level of physical activity in society, can stimulate human to exercise, as well as promote the health of the community and reduces the number of disorders and diseases in old age.

\section{Acknowledgments}

In this regard, I would like to thank the research deputy of the Islamic Azad University of Jahrom to support the implementation of the plan, and all who have participated in this research and gave their valuable time to the researchers.

\section{References}

BESSELL I,DICKS B, WYSOCKI A, KEPNER K. (2012). Understanding Motivation: An Effective Tool for Managers. University of Florida. Institute of Food and Agricultural Science; 2012. Available from: http://edis.ifas.ufl.edu/pdffiles/HR/HR01700.pdf.

BRILL P (2004). Functional fitness for older adults. Champaign (IL): Human Kinetics; 2004.

BROJERDI S, YOUSEFI B, GHOBADI A. (2005). The relationship between general health andburnout among teachers of physical education in Kermanshah province. Proceedings of the 7th National Conference on Physical Education and Sport Sciences. Tabriz University; 2005. (In Persian).

CHHEA C, WARREN N, MANDERSON L. (2010). Health worker effectiveness and retention in rural Cambodia. Rural and remote health. 2010;10(3):2012.

COAKLEY J. (2014). Sports in society: Issues and controversies. 12th ed. New York: McGrawHill Higher Education; 2014.

COX RH. (2011). Sport Psychology: Concepts and Applications. 7th ed. New York: McGrawHill Higher Education; 2011.

DECI E. RYAN RM. (2013). Intrinsic motivation and self-determination in human behavior. New York: Springer Science \& Business Media; 2013.

EKRAMI M, MIRHAJ A. (2015). The Comparison of General health and self-esteem status in the Trained Aged Women in Iran Alzheimer's Association and Other. 2015;14(4):98112. (In Persian).

ERFANI N. (2013). Predicting sports performance based on sports motivations and copetitive. Contemporary Studies on Sport Management. 2013;3(6):49-59.(In Persian).

ESHRAGHI H, KASHEF M, Mehri K .(2012). Comparative study of Iranian universities active 
and inactive academic members' general health conditions. Annals of Biological Research. 2012;3(2):899-907.

FOSTER YA. (1997). Brief aikido training versus karate and golf training and university students' scores on self-esteem, anxiety, and expression of anger. Perceptual and motor skills. 1997;84(2):609-10.

FREDERICK CM, RYANRM. (1993). Differences in motivation for sport and exercise and their relations with participation and mental health. Journal of sport behavior. 1993;16(3):124.

GHODRATNAMA A, HEIDARINEJAD S. (2014). Relationship with physical activity and sports participation motivation among the students in Shahid Chamran University. Sports Management Studies. 2014; 18:189-202. (In Persian).

GILL D, WILLIAMS L, REIFSTECK E. (2017). Psychological dynamics of sport and exercise. 4th ed. Champaign: Human Kinetics; 2017.

GOLDBERG DP, WILLIAMS P. (1988). User's Guide To The General Health Questionnaire. New York: Windsor; 1988.

GOLMOHAMMADI M, LOTFI G, PASBANI H. (2017). Relationship between Motivation of a Company in Sport Activities and General Health of Athletes. 1st National Conference on Achievements of Sports and Health Sciences. Shahid Rajaee Teacher Training University; 2017. (In Persian).

IANNOTTI RJ, CHEN R, KOLOLO H, PETRONYTEG, HAUG E, ROBERTS C. (2012). Motivations for adolescent participation in leisure-time physical activity: international differences. Journal of Physical Activity and health. 2012;10(1):106-14.

JAFARI SIAVASHANI F, GHADIMI B, BEHAEEN B, SAME H. (2010). Study of student motivation for doing physical activities (Health-Related factors against physical appearance related factors). World Applied Sciences Journal. 2010;10(2):322- 326.

LARSON JS. (1996). The World Health Organization's definition of health: Social versus spiritual health. Social Indicators Research. 1996;38(2):181-92.

MARKLAND D, INGLEDEW DK. (1997). The measurement of exercise motives: Factorial validity and invariance across gender of a revised Exercise Motivations Inventory. British Journal of Health Psychology. 1997;2(4):361-76.

PALUSKA SA, SCHWENK TL. (2000). Physical activity and mental health. Sports medicine. 2000;29(3):167-80.

PENEDO FJ, DAHN JR. (2005). Exercise and well-being: a review of mental and physical health benefits associated with physical activity. Current opinion in psychiatry. 2005;18(2):189-93.

RAMEZANI KHALIL ABADI GH. (1996). Investigating the motivations of people 
participating in public sport in Tehran. [MS Thesis]. Tehran: Tarbiat Moalem University; 1996. (In Persian).

SAFAIR S, FATTAHZADEH A. (2003). Global health report in 2003, The Cultural institute of great Ibne sina. The Ministry of Health and Medical Education. 2003:12-5. (In Persian).

SHARIFIRAD G, MOHEBBI S, MATLABI M. (2007). The relationship of physical activity in middle age and cardiovascular problems in old age in retired people in Isfahan, 2006. The Horizon of Medical Sciences. 2007;13(2):57-63. (In Persian).

TAGHAVI MR. (2001). Assessing Reliability And Validity Of The General Health Questionnaire (Ghq). Journal Of Psychology. 2001;4:381-98. (In Persian).

TEIXEIRA PJ, SILVA MN, MATA J, PALMEIRA AL, MARKLAND D. (2012). Motivation, selfdetermination, and long-term weight control. International Journal of Behavioral Nutrition and Physical Activity. 2012;9(1):22.

TEIXEIRA PJ, CARRAÇA EV, MARKLAND D, SILVA MN, RYAN RM. (2012). Exercise, physical activity, and self-determination theory: a systematic review. International journal of behavioral nutrition and physical activity. 2012;9(1):78.

THORP AA, HEALY GN, WINKLER E, CLARK BK, GARDINER PA, OWEN N, et al. (2012). Prolonged sedentary time and physical activity in workplace and non-work contexts: a crosssectional study of office, customer service and call centre employees. International Journal of Behavioral Nutrition and Physical Activity. 2012;9(1):128.

YAGUBI N. (1995). Epidemiology of mental disorders in rural and urban areas Some'esara city. Tehran: Iran University of Medical Sciences; 1995. (In Persian).

YAZDI FEYZABADI V, SEYFADDINI R, GHANDI M, MEHROLHASANI M (2018). The World Health Organization's Definition of Health: A Short Review of Critiques and Necessity of A Shifting Paradigm. Iranian Journal of Epidemiology. 2018;13:155-65.(In Persian). 